\title{
Strategi Mencapai Penghidupan Berkelanjutan Pada Sektor Pariwisata Suku Tengger di Taman Nasional Bromo Tengger Semeru
}

\author{
Muhammad Irsyad ${ }^{*}$, Siti Nurul Rofiqo Irwan², Sri Rahayu Budiani ${ }^{3}$ \\ 1,2,3 Program Studi Magister Kajian Pariwisata Sekolah Pascasarjana Universitas Gadjah Mada \\ *Corresponding Author: muhammadirsyad94@mail.ugm.ac.id
}

\begin{abstract}
Sustainable livelihood is a concept achieved through strategies for utilizing livelihood assets natural, human, social, physical, and financial (DFID, 2001; Scoones, 2009; and Ellis, 2000). The Tengger tribe of Ngadas Village in Bromo Tengger Semeru National Park area (TNBTS) earns income from the agriculture and tourism sectors. Vulnerability due to natural disasters, trend changes in tourist arrivals, and climate change affect the five livelihood assets and livelihood strategies. The objective of this study is to analyze the five livelihood assets owned and to identify livelihood strategies. The descriptive qualitative method is used to assess five livelihoods by weighting and scaling. Livelihood strategies are analyzed by using interactive analysis method with primary and secondary data obtained. The results reveal that natural asset provides the highest value of financial asset, supported by social asset and physical asset. Human asset has the lowest value compared to other assets. The consolidation strategy is the dominant strategy done by dividing works between family members, hiring laborers, and using financial reserves. Other strategies are also carried out through opening a tourism business, planting new agricultural crops, maintaining the environment and culture from damaging external influences.
\end{abstract}

Keywords: Five Livelihood Assets, Tengger Tribe of Ngadas Village, Tourism Sector, Livelihood Strategy

\begin{abstract}
ABSTRAK
Penghidupan berkelanjutan adalah konsep yang dicapai melalui strategi pemanfaatan modal penghidupan, yaitu alam, manusia, sosial, fisik, dan finansial (DFID, 2001; Scoones, 2009; dan Ellis, 2000). Suku Tengger Desa Ngadas di area Taman Nasional Bromo Tengger Semeru (TNBTS) memperoleh pendapatan dari sektor pertanian dan pariwisata. Kerentanan akibat bencana alam, perubahan trends musim kunjungan wisatawan, dan perubahan iklim berpengaruh terhadap lima modal penghidupan dan strategi mata pencaharian. Tujuan penelitian ini adalah menganalisis lima modal penghidupan yang dimiliki dan mengidentifikasi strategi mata pencaharian. Metode deskriptif kualitatif digunakan untuk penilaian lima modal penghidupan menggunakan pembobotan dan pengharkatan. Strategi mata pencaharian dianalisis menggunakan metode analisis interaktif dengan data primer dan data sekunder yang ditemukan. Hasil penelitian memperlihatkan modal alam memberikan pengaruh kepada modal finansial dengan nilai tertinggi didukung dengan modal sosial dan modal fisik. Modal manusia memiliki nilai terendah dibandingkan dengan modal lainnya. Strategi mata pencaharian didominasi strategi konsolidasi dengan pembagian kerja antar anggota keluarga, mempekerjakan buruh, dan menggunakan cadangan finansial. Strategi lainnya juga dilakukan melalui membuka usaha pariwisata, tanaman tumbuhan baru pertanian, mempertahankan lingkungan dan budaya dari pengaruh luar yang merusak.
\end{abstract}

Kata Kunci: lima modal penghidupan, Suku Tengger Desa Ngadas, sektor pariwisata, strategi mata pencaharian

* Corresponding author

Received: March 24, 2020; Revised: March 25, 2020; Accepted: March 28, 2020 


\section{A. PENDAHULUAN}

Desa Ngadas berada di area zona pemanfaatan tradisional TNBTS. Desa ini memiliki keanekaragaman hayati dan keberagaman budaya yang menjadi modal dalam pengembangan pariwisata. Distribusi keberagaman burung di Desa Ngadas meliputi 13 famili dan 23 spesies memiliki potensi untuk kegiatan birdwatching (Widyasari, Hakim, \& Yanuwiadi, 2013). Suku Tengger Desa Ngadas masih mempertahankan kearifan lokal berupa adat istiadat. Tahun 2015 Desa Ngadas ditetapkan sebagai desa wisata adat dan di tahun 2019 menjadi nominasi Indonesia Sustainable Tourism Awards. Kerentanan berupa bencana alam, perubahan iklim, dan trends kunjungan wisatawan dialami Suku Tengger Desa Ngadas.

Meningkatnya kunjungan wisatawan di Desa Ngadas membuat peluang sektor pariwisata meningkat. Suku Tengger Desa Ngadas melakukan usaha wisata seperti menyediakan homestay, menjadi pemandu wisata, transportasi jeep, olahan makanan, dan kesenian. Kunjungan wisatawan di Desa Ngadas tahun 20176.882 wisatawan, tahun 20187.341 wisatawan, dan tahun 20198.985 wisatawan (Disparbud Kab. Malang, 2020). Pariwisata digunakan untuk pengembangan sumber daya keuangan dan memulai pembangunan struktur fisik awal sehingga masyarakat yang berkontribusi dapat memperoleh mata pencaharian dengan berbagai cara (Ahebwa, 2012). Pemenuhan akses terhadap pariwisata diperlukan masyarakat lokal untuk sumber-sumber penghidupan yang dapat menjadi alternatif tambahan penghasilan. Pariwisata diperkenalkan ke suatu komunitas, penting untuk melengkapi dan bukannya menggantikan kegiatan yang ada (Tao \& Wall, 2009).

Mata pencaharian didapatkan dari modal yang dimiliki Suku Tengger Desa Ngadas. Pengelompokkan lima bentuk modal disebut pentagon modal penghidupan, yaitu modal alam, modal manusia, modal fisik, modal finansial, dan modal sosial (DFID, 2001; Scoones, 2009; and Ellis, 2000). Terwujudnya penghidupan berkelanjutan dapat dilihat dari adanya kesempatan bekerja dan berusaha, pencapaian kesejahteraan, adaptasi dan resiliensi penghidupan, pemenuhan pangan, dan keberlanjutan sumber daya alam (DFID 2001; Scoones, 2009; Ellis, 2000). Mewujudkan penghidupan berkelanjutan dapat dilakukan dengan strategi mata pencaharaian. Strategi penghidupan dilakukan dengan cara mengkombinasikan berbagai modal penghidupan yang tersedia (Ellis, 2000). Strategi penghidupan berkelanjutan perlu dilakukan untuk memaksimalkan manfaat pariwisata bagi masyarakat lokal dan untuk memandu praktik pembangunan pedesaan berkelanjutan dengan pariwisata sebagai mata pencaharian (Shen, Hughey, \& Simmons, 2008).

Penelitian sebelumnya yang dilakukan oleh (Batoro, 2012; Simpson, 2007; Widyasari et al., 2013; Lestari, 2013) memberikan penjelasan penghidupan berkelanjutan dalam pariwisata, kondisi Suku Tengger di sekitar Bromo Tengger Semeru, kondisi keanekaragaman fauna burung di Desa Ngadas, dan bencana alam tanah longsor di Desa Ngadas. Perbedaan penelitian yang dilakukan sebelumnya dengan penelitian sekarang adalah pada kondisi pentagon aset yang memuat lima modal yang dimiliki oleh Suku Tengger Desa Ngadas untuk mencapai penghidupan berkelanjutan pada sektor pariwisata. Menggunakan pembobotan, skoring, dan rentan skala untuk menentukan kondisi lima modal yang dimiliki. Strategi yang dilakukan oleh Suku Tengger Desa Ngadas untuk mencapai penghidupan berkelanjutan pada sektor pariwisata diperoleh melalui analisis interaktif.

\section{B. METODE PENELITIAN}

Penelitian menggunakan pendekatan deskriptif kualitatif. Lokasi penelitian berada di Desa Ngadas, Kecamatan Poncokusmo, Kabupaten Malang. Fokus penelitian adalah menganalisis lima modal penghidupan dan mengidentifikasi strategi mata pencaharian. Pengumpulan data diperoleh degan observasi lapangan, wawancara mendalam, dan data sekunder yang terdiri dari zonasi TNBTS, informasi dasar Desa Ngadas, paket wisata, kebijakan terkait, dan penelitian terdahulu. Informan diperoleh dari

12 Jurnal Kepariwisataan: Destinasi, Hospitalitas dan Perjalanan, Volume 4 Nomor 1, 2020: 11-28 
pengelola Desa Wisata Adat Ngadas, Pemerintah Desa Ngadas, Dinas Pariwisata dan Kebudayaan Kabupaten Malang, dan Balai Besar Taman Nasional Bromo Tengger Semeru (BBTNBTS1, 2019). Wawancara mendalam dilakukan kepada Kepala Desa Ngadas, Tokoh Agama, dan Lemabag Desa Wisata Adat Ngadas. Informan dalam wawancara mendalam dipilih berdasarkan keterlibatan langsung dalam pengelolaan Desa Wisata Adat Ngadas, adat istiadat yang masih dilakukan hingga saat ini oleh Suku Tengger Desa Ngadas, dan kondisi masyarakat Desa Ngadas.

Mengetahui lima modal penghidupan dapat dilakukan dengan metode pengharkatan dan pembobotan (Ahebwa, 2012; Ashley, 2000; Mbaiwa \& Stronza, 2010; Qian, Sasaki, Jourdain, Minsun, \& Shivakoti, 2017; Simpson, 2007). Lima modal yang dimiliki Suku Tengger Desa Ngadas akan diketahui kondisinya berada pada tingkatan kelas 1-5. Tahapan untuk menentukan bobot dan skor dengan tahapan sebagai berikut:

a. Menentukan bobot nilai 100 ke lima modal sehingga rata-rata ke lima modal adalah 20. Lima modal diberikan bobot nilai yang sama karena bentuk pentagon aset yang memiliki kesamaan sisi sehinggai bobot masing-masing modal sama (Chambers \& Conway, 1991; DFID, 2001). Nilai bobot pada masing-masing modal dibagi kedalam variabel dan indikator secara merata.

b. Masing-masing indikator diberikan skor untuk dapat menentukan nilai dari masing-masing variabel. Penentuan skor diperoleh menggunakan penilaian skala 1-3. Skala 1 memiliki arti kurang, skala 2 memiliki arti sedang, dan skala 3 memiliki arti baik. Penilaian diberikan berdasarkan fakta dari hasil observasi di lapangan, data primer melalui wawancara mendalam, dan data sekunder yang ditemukan.

c. Memberikan nilai untuk masing-masing indikator dengan melakukan perkalian pada nilai bobot dan nilai skor sehingga didapatkan data untuk modal alam, modal manusia, modal sosial, modal finansial dan modal fisik.

Strategi mata pencaharaian Suku Tengger Desa Ngadas dapat diketahui dengan melakukan analisis interaktif yang diperoleh dari pengamatan langsung, data primer berupa wawancara mendalam dan data sekunder terkait. Lima modal penghidupan dan strategi mata pencaharian dapat diketahui melalui variabel dan indikator yang telah dirumuskan berdasarkan teori dan penelitian terdahulu (Tabel 1).

Tabel 1. Identifikasi Modal Penghidupan dan Strategi Penghidupan

\section{Mengidentifikasi kondisi modal penghidupan Suku Tengger Desa Ngadas pada sektor} pariwisata

\begin{tabular}{|c|c|c|c|c|}
\hline Parameter & Variabel & Indikator & Bobot & Skor \\
\hline \multirow[t]{6}{*}{$\begin{array}{l}\text { 1. Modal } \\
\text { Manusia }\end{array}$} & Pengetahuan & $\begin{array}{lll}\begin{array}{l}\text { Pengetahuan } \\
\text { dimiliki }\end{array} & \text { pariwisata yang } \\
\end{array}$ & 3,3 & 2 \\
\hline & Keterampilan & $\begin{array}{l}\text { Keterampilan yang dimiliki untuk } \\
\text { menunjang pariwisata }\end{array}$ & 3,3 & 2 \\
\hline & Pelatihan & Frekuensi mendapatkan pelatihan & 3,3 & 2 \\
\hline & Pendidikan & $\begin{array}{l}\text { Kesadaran untuk melanjutkan } \\
\text { sekolah ke jenjang pendidikan yang } \\
\text { lebih tinggi }\end{array}$ & 3,3 & 1 \\
\hline & Peran wanita & $\begin{array}{l}\text { Jumlah wanita pada sektor } \\
\text { pariwisata }\end{array}$ & 3,3 & 2 \\
\hline & Kesehatan & Riwayat kesehatan masyarakat & 3,3 & 2 \\
\hline \multirow[t]{4}{*}{ 2. Modal Alam } & Keanekaragaman & Flora & 12 & 3 \\
\hline & lingkungan & Fauna & & \\
\hline & & Sumber mata air & & \\
\hline & Kepemilikan lahan & Lahan untuk usaha wisata & 8 & 2 \\
\hline
\end{tabular}




\begin{tabular}{|c|c|c|c|c|}
\hline & & Fungsi tempat usaha & & \\
\hline \multirow[t]{4}{*}{ 3. Modal Fisik } & \multirow[t]{2}{*}{ Sarana } & Kondisi jalan dan infrastruktur & \multirow[t]{2}{*}{10} & \multirow[t]{2}{*}{3} \\
\hline & & $\begin{array}{l}\text { Infrastruktur layanan desa } \\
\text { (kesehatan, pendidikan, pengairan, } \\
\text { ketersediaan listrik) }\end{array}$ & & \\
\hline & \multirow[t]{2}{*}{ Prasarana } & Jaringan komunikasi & \multirow[t]{2}{*}{10} & \multirow[t]{2}{*}{2} \\
\hline & & $\begin{array}{l}\text { Kondisi fisik usaha wisata (homestay, } \\
\text { jeep, sedan) }\end{array}$ & & \\
\hline \multirow{5}{*}{$\begin{array}{l}\text { 4. Modal } \\
\text { Finansial }\end{array}$} & Cadangan finansial & Jenis tabungan yang dimiliki & 4 & 2 \\
\hline & \multirow[t]{2}{*}{ Akses pinjaman } & Sumber pinjaman & \multirow[t]{2}{*}{8} & \multirow[t]{2}{*}{2} \\
\hline & & Jumlah pinjaman & & \\
\hline & \multirow[t]{2}{*}{ Pendapatan } & Sumber pendapatan & \multirow[t]{2}{*}{8} & \multirow[t]{2}{*}{3} \\
\hline & & Jumlah pendapatan & & \\
\hline \multirow{8}{*}{$\begin{array}{l}\text { 5. Modal } \\
\text { Sosial }\end{array}$} & \multirow{3}{*}{$\begin{array}{l}\text { Partisipasi } \\
\text { berorganisasi }\end{array}$} & Jenis organisasi yang diikuti & \multirow[t]{3}{*}{7,5} & \multirow[t]{3}{*}{2} \\
\hline & & Frekuensi kehadiran & & \\
\hline & & Manfaat yang dirasakan & & \\
\hline & Relasi & Relasi yang dimiliki & 2,5 & 2 \\
\hline & Kepercayaan & Kerjasama yang dilakukan bersama & 2,5 & 1 \\
\hline & $\begin{array}{l}\text { Peluang membangun } \\
\text { kapasitan }\end{array}$ & $\begin{array}{l}\begin{array}{l}\text { Kesempatan terlibat di usaha } \\
\text { pariwisata }\end{array} \\
\end{array}$ & 2,5 & 2 \\
\hline & $\begin{array}{l}\text { Pemasaran kawasan } \\
\text { wisata }\end{array}$ & Promosi yang dilakukan & 2,5 & 2 \\
\hline & Sumberdaya lokal & $\begin{array}{l}\text { Adat istiadat atau tradisi yang } \\
\text { dimiliki }\end{array}$ & 2,5 & 3 \\
\hline \multicolumn{5}{|c|}{ II. Menemukan strategi penghidupan yang dilakukan oleh Suku Tengger Desa Ngadas } \\
\hline \multirow{10}{*}{$\begin{array}{c}\text { Parameter } \\
\text { Strategi } \\
\text { Penghidupan }\end{array}$} & Variabel & \multicolumn{3}{|c|}{ Indikator } \\
\hline & \multirow[t]{3}{*}{ Diversifikasi } & \multicolumn{3}{|l|}{ Membuka usaha pariwisata } \\
\hline & & \multicolumn{3}{|l|}{ Menanam tumbuhan baru untuk pertanian } \\
\hline & & \multicolumn{3}{|l|}{ Membuat objek wisata } \\
\hline & \multirow[t]{3}{*}{ Konsolidasi } & \multicolumn{3}{|l|}{ Pembagian kerja antar anggota keluarga } \\
\hline & & \multicolumn{3}{|l|}{ Mempekerjakan buruh } \\
\hline & & \multicolumn{3}{|l|}{ Menggunakan cadangan finansial } \\
\hline & \multirow[t]{2}{*}{ Keamanan } & \multirow{2}{*}{\multicolumn{3}{|c|}{$\begin{array}{l}\text { Mempertahankan lingkungan kawasan pegunungan } \\
\text { Mempertahankan budaya dari pengaruh luar }\end{array}$}} \\
\hline & & & & \\
\hline & Kompensasi & \multicolumn{3}{|c|}{ Menjual lahan milik pribadi yang tidak produktif } \\
\hline
\end{tabular}

\section{HASIL DAN ANALISIS}

Strategi mata pencaharaian Suku Tengger Desa Ngadas dapat diketahui dengan melakukan analisis interaktif yang diperoleh dari pengamatan langsung, data primer berupa wawancara mendalam dan data sekunder terkait. Lima modal penghidupan dan strategi mata pencaharian dapat diketahui melalui variabel dan indikator yang telah dirumuskan berdasarkan teori dan penelitian terdahulu (Tabel 1).

Suku Tengger Desa Ngadas dapat mencapai penghidupan berkelanjutan dengan kemampuan untuk menghadapi kerentanan, mengakses lima modal penghidupan, dan penerapan strategi mata pencaharaian.

Letak Desa Ngadas berada diantara dua gunung berapi aktif, yaitu Gunung Bromo dan Gunung Semeru. Riwayat erupsi Gunung Bromo paling parah terjadi di tahun 2010-2011. Material vulkanik yang dimuntahkan Gunung Bromo berupa bom, lapili, maupun lava hanya mencapai bagian dalam kaldera, sedangkan material halus seperti abu dan pasir mencapai puluhan kilometer (Zaennudin, 2011). Gunung Bromo mengalami erupsi tidak terus menerus, terakhir terjadi pada tanggal 19 Juli 2019 dengan 
intensitas tipis setinggi 50-200 meter sehingga wisatawan dilarang mendekat ke kawah Gunung Bromo radius $1 \mathrm{~km}$ (VSI ESDM, 2020). Desa Ngadas letaknya jauh dari kawah, sehingga aktivitas masih dapat dilakukan Suku Tengger dan wisatawan.

Topografi Desa Ngadas dengan kontur lahan datar 374,90 Ha, miring $3749 \mathrm{Ha}$, dan berbukit 968,10 Ha (BBTNBTS1, 2019). Kontur lahan miring dan berbukit menjadikannya rentan terhadap bencana alam tanah longsor. Persebaran tanah longsor di Desa Ngadas berada pada wilayah dengan kondisi yang memiliki lereng curam, tanah yang lepas-lepas dan sifatnya berupa longsoran (Lestari, 2013). Penyebab terjadinya tanah longor selain kondisi topografi adalah kondisi pergerakan tanah. Kerentanan pergerakan tanah di Desa Ngadas memiliki status menengah-tinggi (ESDM Jatim, 2014). Diperkuat dengan peta perkiraan wilayah terjadinya gerakan tanah pada Bulan Maret 2019 yang dikeluarkan oleh Badan Geologi Kementerian ESDM bahwa Desa Ngadas memiliki status potensi terjadi gerakan tanah tinggi.

Kebakaran hutan disekitar Desa Ngadas sering terjadi karena faktor alam dan ulah manusia. Kebakaran hutan di TNBTS di tahun 2014 terjadi 7 kali dengan luas 2.415,13 Ha, tahun 201516 kali dengan luas $540 \mathrm{Ha}$, tahun 20171 kali dengan luas $76 \mathrm{Ha}$, dan tahun 201813 kali denagn luas 97, 79 Ha (BBTNBTS2, 2018). Kebakaran terjadi di Blok Peteteh Desa Ngadas pada tanggal 21 Oktober 2019 yang menghanguskan area sepanjang $100 \mathrm{~m}$ dan merembet kedalam $100 \mathrm{~m}$ dengan kerugian lahan hutan 1,5 Ha sehingga menutup akses utama ke Bromo melalui pintu masuk Resort Coban Trisula (Jawapos.com, 2019).

Bencana alam yang terjadi dapat memberikan dampak negatif bagi Suku Tengger dan wisatawan yang berada di Desa Ngadas. Mitigasi terhadap bencana alam dapat dilakukan untuk memberikan keamanan dan kenyamanan. Upaya mitigasi diantaranya adalah pembentukan desa tangguh gunung meletus oleh BPBD Kab. Malang, memperbaiki akses jalan yang tertutup longsor oleh UPT Dinas PU Bina Marga Kec. Tumpang, patroli gabungan Polsek Poncokusumo bersama Muspika Poncokusumo, Resort Coban Trisula BBTNBTS dilakukan untuk pencegahan kebakaran hutan, dan papan peringatan petunjuk arah jika terjadi bencana alam telah terpasang disepanjang jalan.

Kerentanan lainnya yang terjadi adalah trend kunjungan wisatawan di Desa Ngadas dipengaruhi oleh kunjungan wisatawan di Kabupaten Malang dan TNBTS. Perubahan iklim berupa musim kemarau lebih panjang dibadingkan musim penghujan dirasakan Suku Tengger Desa Ngadas tahun 2019. Dampaknya dirasakan musim tanam sektor pertanaian mundur dari jadwal tahun sebelumnya dan musim kunjungan wisatawan lebih ramai jika musim kemarau. Perubahan ini disiasati Suku Tengger Desa Ngadas dengan pembagian waktu untuk malayani wisatawan yang berkunjung dan merawat lahan untuk ditanami komoditas utama kentang.

\section{Analisis Lima Modal Penghidupan Berkelanjutan}

Modal alam, modal manusia, modal sosial, modal fisik, dan modal finansial. Kondisi lima modal penghidupan yang dimiliki oleh Suku Tenger Desa Ngadas menunjukkan hasil nilai tingga hingga tinggi sekali yang diperoleh dari perkalian bobot dengan skor dan penjumlahan hasil variabel di masingmasing modal. Nilai dalam modal penghidupan dapat dilihat dalam tabel berikut (Tabel 2). Lima modal penghidupan dapat dilihat dengan kriteria 10-20 (rendah sekali), 21-30 (rendah), 31-40 (sedang), 41-50 (tinggi), dan 51-60 (tinggi sekali).

Tabel 2. Lima Modal Penghidupan Berkelanjutan

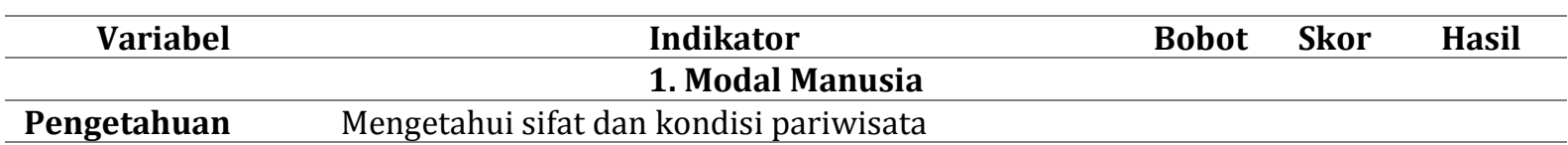




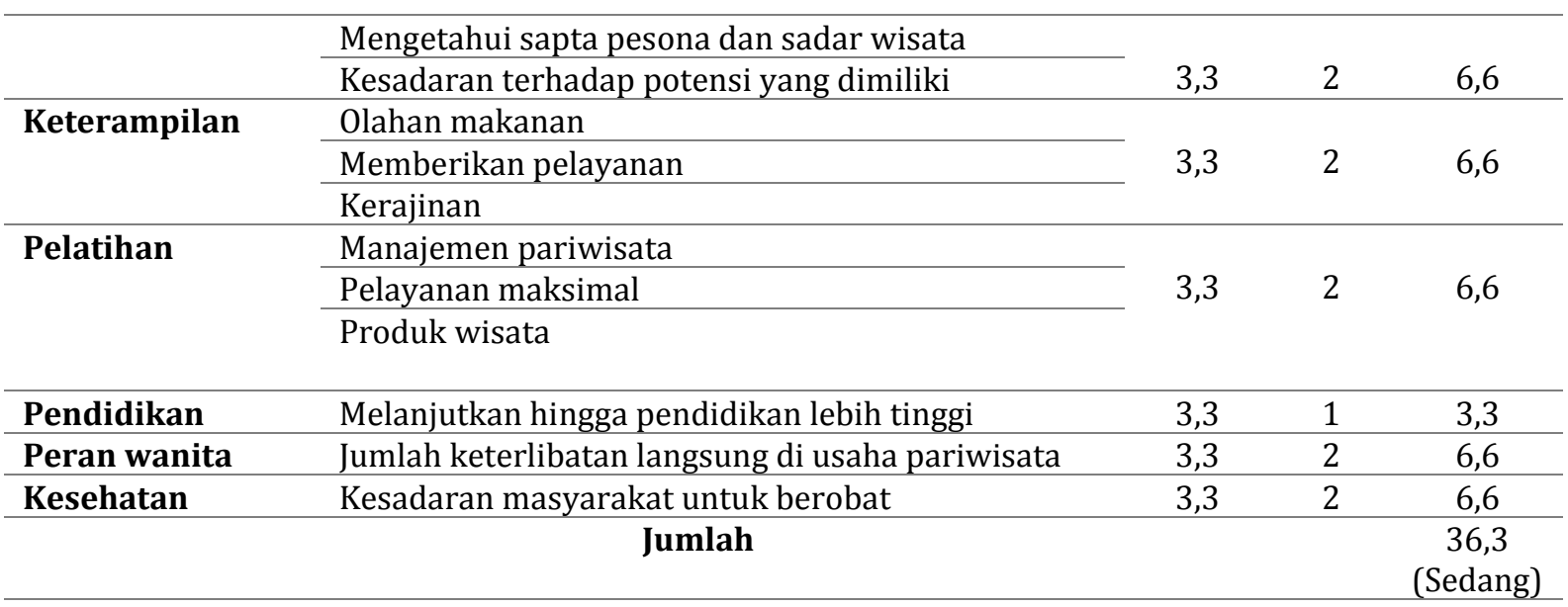

\section{Lingkungan \\ Kepemilikan Lahan}

Keanekaragaman
Kondisi flora

Kondisi fauna

Kondisi sumber mata air

Fungsi lahan untuk pertanian

Fungsi lahan untuk usaha wisata

Fungsi laha untuk usaha lainnya

\section{Modal Alam}

$12 \quad 3 \quad 36$

$8 \quad 2 \quad 16$

Jumlah

\section{Modal Fisik}

\begin{tabular}{|c|c|c|c|c|}
\hline \multirow[t]{2}{*}{ Sarana } & Kondisi jalan dan infrastruktur & \multirow[b]{2}{*}{10} & \multirow[b]{2}{*}{3} & \multirow[b]{2}{*}{30} \\
\hline & $\begin{array}{l}\text { Infrastruktur layanan desa (kesehatan, pendidikan, } \\
\text { pengairan, ketersediaan listrik) }\end{array}$ & & & \\
\hline \multirow[t]{3}{*}{ Prasarana } & Jaringan komunikasi & \multirow[t]{3}{*}{10} & \multirow[t]{3}{*}{2} & \multirow[t]{2}{*}{20} \\
\hline & \multirow{2}{*}{$\begin{array}{l}\text { Konaisi nisik usana wisata (nomestay, jeep, sedan) } \\
\text { Jumlah }\end{array}$} & & & \\
\hline & & & & $\begin{array}{c}50 \\
\text { (Tinggi) }\end{array}$ \\
\hline \multicolumn{5}{|c|}{ 4. Modal Finansial } \\
\hline $\begin{array}{l}\text { Cadangan } \\
\text { finansial }\end{array}$ & $\begin{array}{l}\text { Kemauan untuk menyimpan keuangan di } \\
\text { koperasi/bank }\end{array}$ & 4 & 2 & 8 \\
\hline \multirow[t]{2}{*}{ Akses pijaman } & Meminjam untuk kebutuhan mendadak & \multirow[b]{2}{*}{8} & \multirow[b]{2}{*}{2} & \multirow[b]{2}{*}{16} \\
\hline & Meminjam untuk kebutuhan usaha & & & \\
\hline Pendapatan & Pendapatan dari usaha yang dilakukan & 8 & 3 & 24 \\
\hline & Jumlah & & & 48 \\
\hline
\end{tabular}

\section{Modal Sosial}

\begin{tabular}{|c|c|c|c|c|}
\hline \multirow{3}{*}{$\begin{array}{l}\text { Partisipasi } \\
\text { berorganisasi }\end{array}$} & Keikutsertaan dalam organisasi & \multirow{3}{*}{7,5} & \multirow{3}{*}{2} & \multirow{3}{*}{15} \\
\hline & Frekuensi kehadiran & & & \\
\hline & Manfaat yang dirasakan & & & \\
\hline Relasi & Relasi dengan stakeholders & 2,5 & 2 & 5 \\
\hline Kepercayaan & Kerjasama yang dilakukan bersama & 2,5 & 1 & 2,5 \\
\hline $\begin{array}{l}\text { Peluang } \\
\text { membangun } \\
\text { kapasitas }\end{array}$ & Kesempatan terlibat di usaha pariwisata & 2,5 & 3 & 7,5 \\
\hline $\begin{array}{l}\text { Pemasaran } \\
\text { kawasan wisata }\end{array}$ & Promosi yang dilakukan & 2,5 & 2 & 5 \\
\hline $\begin{array}{l}\text { Sumberdaya } \\
\text { lokal }\end{array}$ & $\begin{array}{l}\text { Adat istiadat atau tradisi yang dilakukan hingga saat } \\
\text { ini }\end{array}$ & 2,5 & 3 & 7,5 \\
\hline & Jumlah & & & 42,5 \\
\hline
\end{tabular}

16 |Jurnal Kepariwisataan: Destinasi, Hospitalitas dan Perjalanan, Volume 4 Nomor 1, 2020: 11-28 
Sumber: Hasil Olahan Peneliti, 2020

\section{Modal manusia}

Suku Tengger di Desa Ngadas adalah subjek dari modal manusia yang dimiliki saat ini. Komponen modal manusia terdiri dari umur, pendidikan, lama bekerja dalam tahun dan bahasa (Cornelius, Tsuda, \& Valdez, 2003). Modal manusia sebagai pengetahuan, keterampilan, dan komponen yang dapat mendukung pencapaian kesejahteraan personal, sosial, dan ekonomi (OECD dalam Stroombergen, Rose, \& Nana, 2002).

...Pada awalnya hanya beberapa orang saja yang melakukan usaha di bidang pariwisata Semakin banyaknya wisatawan yang datang di Desa Ngadasn jumlahnya ikut bertambah. Kami yang memeperoleh pelatihan pariwisata lebih dulu tidak sungkan untuk berbagi pengetahuan tentang pariwisata kepada masyarakat yang ingin memulai usaha pariwisata.... (Lembaga Desa Wisata Adat Ngadas, wawancara Bulan Januari 2020).

Pariwisata menjadi alternatif bagi penghidupan yang dilakukan oleh Suku Tengger yang sebelumnya memperoleh hasil dari pertanian. Jumlah penduduk di Desa Ngadas di tahun 2019 sebesar 1896 orang yang memilih untuk usaha pariwisata hanya $5 \%$ atau berjumlah 50 orang. Melakukan usaha pariwisata secara tidak langsung akan mengetahui pengetahuan tentang pariwisata melalui interaksinya dengan wisatawan. Interaksi secara terus-menurus akan menjadi pendorong bagi pelaku usaha wisata untuk menambah wawasan terkait wisatawan.

Pelatihan telah didapatkan Suku Tengger Desa Ngadas. Pelatihan berasal dari Kementerian Pariwisata, Balai Besar TNBTS, Dinas Kebudayaan dan Pariwisata Provinsi Jawa Timur, Dinas Pariwisata dan Kebudayaan Kabupaten Malang, LSM Pariwisata seperti EJEF (East Java Ecotourism Forum), dan Perguruan Tinggi melalui LPPM.

...Pelatihan terakhir yang diselenggarakan dengan peserta dari Desa Ngadas adalah pengelolaan homestay. Pelatihan ini langsung diberikan oleh Kementerian Pariwisata melalui praktik langsung. Berlokasi di Desa Ngadas beberapa materi dan praktik terkait pelayanan, penataan kamar, dan penyajian makanan diberikan... (Kasi Destinasi Wisata Alam dan Buatan Disparbud Kab. Malang, wawancara Bulan Desember 2019).

Penyelenggara pelatihan memberikan materi seperti sapta pesona dan sadar wisata, manajemen kelembagaan, pengelolaan homestay, kepemanduan wisata, olahan produk lokal, dan materi lainnya terkait pariwisata. Capaian dari pelatihan salah satunya adalah keterampilan yang didapatkan untuk moengolah makanan, memberikan pelayanan, dan kerajinan. Olahan makanan diolah dari bahan-bahan hasil pertanian seperti kentang dan terong belanda. Produk yang telah dikemas dan diperjualbelikan diantaranya adalah keripik kentang, sambal goreng kentang, stick kentang, selai terong belanda, sirup terong belanda, dan permen terong belanda.

...Kami bisa mengolah hasil panen seperti kentang, carica, dan terong belanda karena pelatihan yang diberikan oleh Taman Nasional. Akan tetapi olahan tersebut hanya kami buat ketika bahan baku sedang tersedia banyak atau disaat musim panen dan ada pesananan dalam jumlah banyak.... (Anggota Lembaga Desa Wisata Adat Ngadas, wawancara Bulan Januari 2020).

Pelayanan dilakukan disetiap usaha pariwisata, tetapi yang paling sering berinteraksi dengan wisatawan adalah pengelola homestay dan pemandu wisata.

Keterlibatan pria lebih banyak dibandingkan wanita, mengingat jumlah laki-laki di desa 985 lakilaki dan 911 perempuan. Wanita Suku Tengger Desa Ngadas terlah terlibat dalam usaha wisata Desa Wisata Adat Ngadas. Keterlibatan wanita dalam usaha pariwisata dapat dilihat melalui pengelolaan homestay, pembuatan olahan makanan, kepemanduan wisata, dan penampilan kesenian. Wanita juga 
memiliki peran untuk melakukan bisnis dengan membuka warung di kawasan TNBTS. Dahulu pria yang mencari uang melalui bertani dan usaha lainnya, sekarang wanita bisa membantu melalui beragam pilihan aktivitas.

Pendidikan formal Suku Tengger Desa Ngadas rendah dibandingkan dengant target nasional untuk wajib sekolah sembilan tahun atau hingga tamat SMP. Pendidikan formal rata-rata di Desa Ngadas masih hingga tamat sekolah dasar sebesar 81,5\% (RPJM Desa, 2018). Selain pendidikan formal, menurut Undang-undang no. 20 tahun 2003 tentang sistem pendidikan nasional terdapat jenis pendidikan lain, yaitu pendidikan non formal dan informal. Pendidikan informal didapatkan setiap Suku Tengger melalui orang tua dan lingkungannya tentang pertanian. Pendidikan non formal diperoleh Suku Tengger diperoleh dengan pelatihan yang diikuti.

Penyakit yang sering di derita oleh Suku Tengger di Desa Ngadas diantaranya adalah malaria, penyakit sistem otot dan jaringan pengikat (RPJM Desa, 2018). Gejala masyarakat yang terserang penyakit relatif tinggi, antara lain disebabkan oleh infeksi pernafasan akut bagian atas, penyakit sistem otot dan jaringan pengikat. (BBTNBTS4, 2018). Suku Tengger di Desa Ngadas mengalami cacat tercatat penderita bibir sumbing berjumlah 2 orang, tuna wicara 6 orang, tuna rungu 12 orang, dan tuna netra 4 orang (RPJM Desa, 2018). Pengendalian jumlah penduduk dapat dilakukan dengan melakukan program keluarga berencana. Peserta keluarga berencana (KB) aktif pada tahun 2018 di Desa Ngadas berjumlah 75 orang (RPJM Desa, 2018).

\section{Modal alam}

Modal alam yang dapat diakses oleh Suku Tengger Desa Ngadas dipengaruhi oleh fungsi zonasi TNBTS. Modal alam bersumber dari penguasaan rumahtangga akan lahan, air, dan kemudahan lainnya yang mendukung kehidupan rumah tangga dalam bertahan hidup (Scoones, 2009 ; DFID, 2001). Pemanfaatan modal alam yang dilakukan oleh Suku Tengger selain pertanian adalah untuk pariwisata. Pariwisata mempengaruhi akses masyarakat ke modal alam baik secara langsung (menggunakan atau merusak sumber daya alam) dan secara tidak langsung (mempengaruhi cara mereka dikelola) (Ashley, 2000).

Keanekaragaman hayati dapat dilihat dari kondisi biotik dan abiotik yang tersebar disekitar Desa Ngadas. Fauna yang tersebar diseluruh kawasan TNBTS berjumlah 24 Aves, 11 Mamalia, 1 Reptil, dan 2 Insekta termasuk didalamnya Elang Jawa, Elang Hitam, Lutung Jawa, dan Macan Tutul (BBTNBTS3, 2019). Pengetahuan keanekaragaman jenis hewan di lingkungan masyarakat Tengger berjumlah 120 jenis yang terdiri dari hewan peliharaan yang dimanfaatkan masyarakat Tengger terdiri dari Aves (8 jenis), Mamalia (10 jenis), ikan danau (3 jenis), dan jenis ikan berasal dari luar Tengger adalah ikan kering (3 jenis), Decapoda ( 2 jenis) dan binatang liar di sekitar mereka meliputi, Mamalia (32 jenis), Reptilia ( 9 jenis), Aves (64 jenis), Diptera (2 jenis), Arachnidae (1 jenis), Grylotaipidae (1 jenis), Hypnoptera (1 jenis) (Batoro, 2012). Jenis flora endemik TNBTS adalah Bunga Anggrek. TNBTS memeliki flora (Anggrek 13, pohon 113, palma 7, perdu 52, bambu 2, liana 27, rumput 14, terna 81, paku 8) dengan beberapa flora endemik seperti Anggrek Tosari (Habenaria tosariensis) di Pananjakan, Anggrek Udang (Dendrobium jacobsonii) di Kalimati dan Gunung Semeru (BBTNBTS3, 2019). 326 jenis tumbuhan yang digunakan sebagai bahan pangan 75 jenis, bahan obat 121 jenis, bahan racun 7 jenis, bahan bangunan (22 jenis), bahan peralatan dan teknologi lokal (22 jenis), bahan tali temali (5 jenis), bahan pembungkus 4 jenis, bahan bumbu 23 jenis, bahan kayu bakar 16 jenis, bahan pakan ternak 44 jenis, jenis tumbuhan konservasi 137 jenis, bahan buah-buahan 49 jenis, bahan ritual 94 jenis, bahan pewarna 8 jenis, bahan kosmetika 10 jenis, bahan rokok dan nginang 10 jenis dan jenis tanaman hias 140 jenis (Batoro, 2012).

18 Jurnal Kepariwisataan: Destinasi, Hospitalitas dan Perjalanan, Volume 4 Nomor 1, 2020: 11-28 
Suku Tengger Desa Ngadas memanfaatkan sumber mata air untuk konsumsi, kebersihan, dan kebutuhan pertanian. Sumber air yang digunakan adalah Sungai Goa dan Sungai Gentong. Dikelola langsung oleh Suku Tengger dengan izin yang diberikan untuk pemanfaatan secara non komersil. Terdapat 50 titik sumber air (mata air dan sungai) dan 6 danau di kawasan TNBTS (BBTNBTS1, 2019). 35 titik telah ditetapkan sebagai kawasan pemanfaatan air dan sumber air dengan Surat Keputusan Direktur Jenderal Konservasi Sumber Daya Alam dan Ekosistem Nomor: SK.445/KSDAE/SET/KSA.3/12/2018 tanggal 28 Desember 2018 tentang Penetapan Kawasan Pemanfaatan Air dan Sumber Air (BBTNBTS1, 2019).

Lahan yang dimiliki dan dimanfaatkan Suku Tengger Desa Ngadas merupakan lahan turun menurun. Suku Tengger lebih lama mendiami kawasan Bromo Tengger Semeru sebelum ditetapkannya menjadi Taman Nasional.

...Memang disekitar Desa Ngadas merupakan zona tradisional yang dimanfaatkan oleh masyarakat untuk bertani. Akan tetapi ada zona lainnya seperti zona pemanfaatan dan zona rimba. Secara struktural di sekitar Desa Ngadas merupakan wilayah dari Resort Coban Trisula... (Kepala SPTN 2 BBTNBTS, wawancara Bulan Januari 2020).

Desa Ngadas berada di dalam kawasan pengelolaan Resort PTN Coban Trisula BBTNBTS. Desa Ngadas merupakan kawasan dengan sistem zonasi tradisional dengan luas 977,71 Ha dan pemanfaatan dengan luas 70,34 ha (BBTNBTS1, 2019). Pemanfaatan lahan di Desa Ngadas seperti tanah kering untuk pertanian $354 \mathrm{Ha}$, bangunan dan pekarangan $30 \mathrm{Ha}$, dan lainnya $1 \mathrm{Ha}$ (BBTNBTS1, 2019). Suku Tengger memiliki ketergantungan pada lahan yang dikelola langsung dan tidak langsung. Secara langsung memanfaatkan untuk pertanian di Zona Tradisional yang secara turun-menurun telah diwariskan. Komoditas pertanian yang dominan saat ini adalah kentang, dan jenis lainnya adalah kobis dan bawang daun.

...Pastinya yang kami lembaga jual ke wisatawan adalah kondisi Desa Ngadas dengan Suku Tengger, aktivitas keseharaian seperti pergi ke lahan pertanian, dan disetiap paket wisata yang kami tawarkan ada keindahan Gunung Bromo dan sekitarnya kami berikan, Sejak dahulu memang keberadaan Bromo menjadi atraksi utama, daripada Desa Ngadas hanya sebagai perlintasan Jeep dan dapat debu saja, maka kami mencoba menawarkan keindahan alam disekitar desa... (Lembaga Desa Wisata Adat Ngadas, Wawancara Bulan Januari 2020).

Pariwisata secara tidak langsung memanfaatkan keindahan lanskap Gunung Bromo untuk wisatawan.

\section{Modal fisik}

Sarana dan prasarana menjadi kebutuhan dasar bagi Suku Tengger yang tinggal di Desa Ngadas dan wisatawan yang berkunjung. Kemudahan akses terhadap sarana dan prasarana yang mendukung sumber penghidupan merupakan bentuk dari penguasaan sumberdaya fisik (Scoones, 2009). Sarana dan prasarana yang dimiliki oleh Suku Tengger diantaranya adalah kondisi jalan dan infrastruktur, jaringan komunikasi, infrastruktur layanan desa, dan kondisi fisik usaha wisata. Bromo Tengger Semeru memiliki status sebagai Kawasan Strategis Pariwisata Nasional, top 10 destinasi pariwisata Indonesia, dan Taman Nasional. Letak Desa Ngadas di dalam kawasan menjadikannya subjek dalam pembangunan.

Aksesibilitas menuju Desa Ngadas dari Malang dapat ditempuh dengan jarak 18 Km Malang ke Tumpang, $12 \mathrm{Km}$ Tumpang ke Gubuklakah, 16 Km Gubugklakah ke Ngadas, 1 Km Ngadas ke Jemplang, dan $10 \mathrm{Km}$ Jemplang ke Gunung Bromo (BBTNBTS1, 2019). Aksesibilitas menuju Bromo Tengger Semeru melalui Kabupaten Malang telah dengan mudah diakses oleh roda 4. Kondisi jalan menanjak dan berkelok setelah memasuki kawasan, sehingga perlu meningkatkan kewaspadaan dalam berkendara. Kecelakaan lalu lintas sering terjadi di antara gerbang masuk Coban Trisula hingga Desa Ngadas. Total kecelakaan dari tahun 2015-2018 ada 25 kejadian yang melibatkan kendaraan roda 2 dan roda 4 
(BBTNBTS2, 2018). Tahun 2019 terdapat 14 kali kecelakaan lalu lintas yang disebabkan oleh tidak menguasai jalur dan kondisi kendaraan hingga korban meninggal 2 orang.

...Kami sudah berupaya memberikan peringatan berupa rambu-rambu lalu lintas yang sifatnya berbahaya. Gerbang masuk sebagai tempat pemberhentian untuk pembelian tiket masuk kawasan kami juga sudah memasang baliho besar dengan gambar korban kecelakaan sebagai pengingat. Kami juga mengingatkan kepada pengendara sepeda motor matic untuk berhati-hati karena jalan dan kendaraan tidak sesuai dan sering hilang cengkraman pada rem... (Kepala SPTN 2 BBTNBTS, wawancara Bulan Januari 2020).

Pembangunan aksesibilitas selain memudahkan menuju Bromo Tengger Semeru juga menjamin keselamatan pengendara.

Kebutuhan akan akses informasi saat ini menjadi kebutuhan yang tidak dapat ditinggalkan. Untuk mempermudah akses informasi melalui media online dengan jangkauan luas memperlukan dukungan sarana. Sarana yang ada di TNBTS dalam mempermudah akses informasi telah tersedia.

...Homestay di rumah saya pasang wifi karena tidak semua orang kartunya Telkomsel. Ini saya lakukan juga untuk memberikan layanan kepada wisatawan yang menginap. Wisatawan dapat menggunakannya semaksimal mungkin jika berada didalam rumah... (Lembaga Desa Wisata Adat Ngadas, wawancara Bulan Januari 2020).

Hal ini dapat dilihat melalui sarana repeater yang telah terpasang di seluruh kawasan berjumlah 30 tower (BBTNBTS1, 2019). Sarana prasarana yang telah tersedia di Desa Ngadas diantaranya adalah TK/Ra 1 sekolah, SDN 2 sekolah, SMPN satu atap 1 sekolah, Vihara 1, Pura 1, Masjid 3, Mushola 3, Praktek Bidan 1, Posyandu 2, dan Polindes 2 (RPJM Desa, 2018 dan BPS Kab. Malang, 2019).

Fisik dari produk wisata yang telah tersedia diantaranya adalah mobil jeep, mobil panther, bangunan rumah, dan perlengkapan dapur untuk membuat olahan, bangunan warung, dan perlengkapan kesenian seperti kostum dan alat musik. Modal fisik dibangun untuk memenuhi kebutuhan Suku Tengger dan Wisatawan. Meningkatnya kunjungan wisatawan ke Bromo Tengger Semeru menjadi peluang dalam pembangunan fisik yang dilakukan untuk meningkatkan kualitas destinasi pariwisata Bromo Tengger Semeru.

\section{Modal finansial}

Penghasilan diperoleh Suku Tengger dari sektor pertanian dan pariwisata. Sumber keuangan yang digunakan untuk mencapai tujuan penghidupan melalui cadangan milik sendiri atau lembaga dan aliran dana teratur (DFID, 2001). Selain keuangan, modal finansial dapat berubah menjadi bentuk fisik yang memiliki nilai. Mengalihkan modal finansial dalam bentuk lain seperti kepemilikan ternak sebagai penyimpanan kekayaan (Ellis, 2000).

Pendapatan diperoleh dari hasil setiap ada kunjungan wisatawan dan panen pertanian. Kunjungan wisatawan diperoleh setiap bulannya yang merupakan hasil kerjasama dengan biro perjalanan wisata Kanada G-Adventures.

...Dengan adanya pariwisata kami mendapatkan penghasilan langsung setiap bulannya denga kunjungan wisatawan dari G-Adventures. Pengahsilan ini kami dapatkan dengan memberikan pelayanan kepada wisatawan sesuai standar yang telah diberikan oleh G-Adventures. Sebelumnya kami hanya beberapa bulan sekali mendapatkan penghasilan dari pertanian yang juga membutuhkan pengeluaran untuk pupuk dan biaya perawatan lainnya... (Lembaga Desa Wisata Adat Ngadas, wawancara pada Bulan Januari 2020).

Pendapatan dari usaha yang dilakukan diperoleh dari usaha-usaha wisata yang dilakukan seperti trasportasi bagi wisatawan berupa jeep dan panther, sebagian kamar rumah digunakan untuk homestay, pemandu wisata, olahan konsumsi yang dilakukan oleh ibu-ibu, dan kesenaian yang ditampilkan.

20 Jurnal Kepariwisataan: Destinasi, Hospitalitas dan Perjalanan, Volume 4 Nomor 1, 2020: 11-28 
Lembaga Desa Wisata Adat Ngadas memiliki produk wisata berupa tiga paket wisata yang telah ditawarkan kepada wisatawan (Tabel 3).

Perkiraan perhitungan dilakukan untuk menghitung dampak ekonomi dari kunjungan wisatawan di Desa Ngadas. Dari Total kunjungan setiap tahunnya mulai tahun 2017-2019 total peamsukan yang diperoleh Lembaga Desa Wisata Adat Ngadas sebesar Rp.229.600.000 (Tabel 4). Perkiraan dilakukan dengan asumsi bahwa wisatawan yang telah berkunjung ke Desa Wisata Adat Ngadas membeli paket wisata yang telah ada (Tabel 5).

Sumber pendapatan lainnya berasal dari lahan pertanian dengan komoditas utama Kentang. Harga kentang bervariasi, rata-rata Rp. $7.000-12.000 / \mathrm{kg}$. Total lahan pertanaian sama dengan luas total Zona Tradisional yang ada di Resort Coban Trisula BBTNBTS seluas 1.012 Ha. Setiap kali panen rata-rata lahan dengan luas $1 \mathrm{Ha}$ mendapatkan hasil 8 ton. Perhitungan perolahan hasil panen dari komoditas utama Kentang dapat dilihat dalam tabel berikut (Tabel 6).

Tabel 3. Paket Wisata Desa Wisata Adat Ngadas

\begin{tabular}{|c|c|c|}
\hline Paket Wisata & Itinerary & Harga \\
\hline Savari Agro & $\begin{array}{l}\text { Transportasi PP, Pemandu wisata } \\
\text { lokal, Konsumsi di kebun, } \\
\text { Homestay, Konsumsi di homestay, } \\
\text { Jeep Bromo }\end{array}$ & $\begin{array}{l}\text { Rp. 550.000/pax (minimal } 10 \\
\text { orang) }\end{array}$ \\
\hline Jelajah Kampung & $\begin{array}{l}\text { Transportasi PP, Homestay, } \\
\text { Makan malam \& Cerita sejarah, } \\
\text { Jeep Bromo \& Sarapan, Jelajah } \\
\text { kampung }\end{array}$ & $\begin{array}{l}\text { Rp. 200.000/pax (minimal } 10 \\
\text { orang) }\end{array}$ \\
\hline Jalur Leluhur & $\begin{array}{l}\text { Transportasi PP, Homestay, } \\
\text { Makan malam \& Cerita sejarah, } \\
\text { Jelajah kampung, Jalur leluhur \& } \\
\text { Makan siang, Jeep Bromo }\end{array}$ & $\begin{array}{l}\text { Rp. 350.000/pax (minimal } 8 \\
\text { orang) }\end{array}$ \\
\hline
\end{tabular}

Tabel 4. Pemasukan Tahunan Wisatawan G-Adventures

\begin{tabular}{|c|c|c|c|c|c|}
\hline Tahun & Wisatawan & Harga & Total Harga & Pemasukan & $\begin{array}{c}\text { Total } \\
\text { Peamasukan }\end{array}$ \\
\hline 2017 & 52 & \multirow{3}{*}{$\begin{array}{c}\text { Rp. } \\
\text { 350.000/pax } \\
\text { (minimal } 8 \\
\text { orang) }\end{array}$} & \multirow[t]{3}{*}{ Rp. 2.800.000 } & 18.200 .000 & \multirow{3}{*}{$\begin{array}{c}\text { Rp. } \\
\text { 229.600.000 }\end{array}$} \\
\hline 2018 & 254 & & & 88.900 .000 & \\
\hline 2019 & 350 & & & 122.500 .000 & \\
\hline
\end{tabular}

Sumber: Hasil Olahan Peneliti, 2020

Tabel 5. Perkiraan Pemasukan Tahunan Berdasarkan Paket Wisata

\begin{tabular}{|c|c|c|c|c|}
\hline Tahun & Wisatawan & Harga & Total Harga & Pemasukan \\
\hline \multicolumn{5}{|c|}{ Paket Wisata Savari Agro } \\
\hline 2017 & 6.882 & \multirow{3}{*}{$\begin{array}{l}\text { Rp. } 550.000 / \text { pax } \\
\text { (minimal } 10 \\
\text { orang) }\end{array}$} & \multirow[t]{3}{*}{ Rp. 5.500 .000} & Rp. 3.785.100.000 \\
\hline 2018 & 7.341 & & & Rp. 4.037.550.000 \\
\hline 2019 & 8.985 & & & Rp. 4.941.750.000 \\
\hline \multicolumn{5}{|c|}{ Paket Wisata Jelajah Kampung } \\
\hline 2017 & 6.882 & \multirow{3}{*}{$\begin{array}{l}\text { Rp. } 200.000 / \text { pax } \\
\text { (minimal } 10 \\
\text { orang) }\end{array}$} & \multirow[t]{3}{*}{ Rp. 2.000.000 } & Rp. 1.376.400.000 \\
\hline 2018 & 7.341 & & & Rp. 1.468 .200 .000 \\
\hline 2019 & 8.985 & & & Rp. 1.797.000.000 \\
\hline \multicolumn{5}{|c|}{ Paket Wisata Jalur Leluhur } \\
\hline 2017 & 6.882 & Rp. 350.000/pax & Rp. 2.800 .000 & Rp. 2.408.700.000 \\
\hline
\end{tabular}




\begin{tabular}{cccc}
\hline $\mathbf{2 0 1 8}$ & 7.341 & (minimal 8 orang) & Rp. 2.569.350.000 \\
$\mathbf{2 0 1 9}$ & 8.985 & Rp. 3.144.750.000 \\
\hline \multicolumn{2}{c}{ Sumber: Hasil Olahan Peneliti, 2020 }
\end{tabular}

Tabel 6. Perkiraan Pendapatan Tahunan Panen Kentang

\begin{tabular}{cccccc}
\hline & Harga & Luas Lahan & Hasil Panen & Periode & Pendapatan \\
\hline Terendah & $7.000 / \mathrm{Kg}$ & $1.012 \mathrm{Ha}$ & $8.000 \mathrm{Kg} / \mathrm{Ha}$ & 2 Kali/Thn & $\begin{array}{c}\text { Rp. } \\
113.344 .000 .000\end{array}$ \\
& & & & 2 Kali/Thn & $\begin{array}{c}\text { Rp. } \\
\text { Tertinggi }\end{array}$ \\
& $12.000 / \mathrm{Kg}$ & $1.012 \mathrm{Ha}$ & $8.000 \mathrm{Kg} / \mathrm{Ha}$ & & 194.304 .000 .000 \\
\hline
\end{tabular}

Sumber: Hasil Olahan Peneliti, 2020

\section{Modal sosial}

Suku Tengger tidak akan lepas dari modal sosial dalam memperoleh mata pencaharian. Modal sosial adalah sumberdaya yang melekat pada hubungan keluarga dalam organisasi komunitas dan yang berguna bagi perkembangan kognitif atau sosial anak yang masih muda (Coleman, 1994 dalam Field, 2010). Modal sosial tidak berwujud tetapi dapat diwujudkan dalam relasi dan hubungan di antara orangorang (Coleman, 2010). Modal sosial dapat disebut sebagai modal jika dapat membuat sumberdaya yang bisa dimanfaatkan untuk memberdayakan aktor atau individu dan kelompok untuk mencapai tujuan bersama (Field, 2010). Modal sosial yang dimiliki oleh Suku Tengger Desa Ngadas dapat dilihat melalui partisipasi berorganisasi, relasi, kerjasama, peluang membangun kapasitas, pemasaran, dan sumberdaya lokal.

Salah satu perantara untuk mencapai tujuan bersama adalah melalui pembentukan organisasi. Desa memiliki pengurus organisasi atau yang disebut sebagai pemerintah desa. Lembaga Pemerintahan Desa Ngadas terdiri dari Pemerintah Desa, Badan Permusyawaratan Desa (BPD), dan Lembaga Pemberdayaan Masyarakat Desa (LPMD) (RPJM Desa, 2018). Pengembangan sektor pariwisata di Desa Ngadas dilakukan oleh Lembaga Desa Wisata Adat Ngadas dengan struktur kelembagaan terdiri dari ketua, wakil, sekretaris, bendahara, seksi penggali potensi, seksi produk wisata, seksi pemasaran, seksi keamanan, seksi sapta pesona, seksi homestay, seksi transportasi, seksi humas, seksi pemandu wisata. Total keseluruhan anggota dengan struktural kelembagaan sejak dibentuk berjumlah 47 orang. Seiring berjalannya waktu, anggota yang aktif hingga saat ini berjumlah \pm 20 orang.

...Anggota selama ini koordinasi hanya terkait kedatangan wisatawan G-Adventures, anggota telah memiliki tugas dan gilirannya masing-masing, penjemputan dengan Panther pergi ke titik jemput di Kota Malang, Homestay memberikan pelayanan di rumah, dan tugas lainnya. Berkumpul dengan anggota lainnya ketika sedang ada pembahasan terkait keuangan dilakukan setiap tahunnya 2-3 kali. Untuk kegiatan rutin yang diselanggarakan selama ini hanya untuk memberikan pelayanan kepada wisatawan G-Adventures... (Lembaga Desa Wisata Adat Ngadas, wawancara Bulan Januari 2020).

Kelompok lainnya yang telah terbentuk di Desa Ngadas adalah kelompok pemanfaat sumber mata air, kelompok pengelola zona tradisional hutan non kayu, dan kelompok masyarakat mitra Polhut. Kelompok kesenian Desa Ngadas terdiri dari perkumpulan terbang jidor 1 kelompok, jaran kencak 1 kelompok, kuda lumping 2 kelompok, bantengan 1 kelompok, band / dangdut 1 kelompok, campursari 1 kelompok, dan tarian daerah 1 kelompok (RPJM Desa, 2018). Karang Taruna Desa Ngadas memiliki nama Hipekarta (Himpunan Pemuda Pemudi Karang Taruna)dengan anggota 21 orang.

22 |Jurnal Kepariwisataan: Destinasi, Hospitalitas dan Perjalanan, Volume 4 Nomor 1, 2020: 11-28 
Pihak luar Desa Ngadas melalui lembaga-lemabag memberikan dorongan pada lembaga internal Desa Ngadas untuk mencapai tujuan bersama. Dorongan ini diberikan oleh stakeholders yang terdiri dari akademisi, bisnis, komunitas, pemerintah, dan media. Bentuk dorongan salah satunya adalah peluang membangun kapasitas.

...Awalnya saya tidak melakukan usaha pariwisata, hanya mendapatkan penghasilan dari bertani. Ketika melihat tetangga rumhanya didatangi bule saya punya keinginan bertanya kenapa bisa begitu. Setelah bertanya dan tertarik karena dari kedatangan bule juga kedatangan rejeki. Akhirnya rumah saya yang masih ada beberapa kamar kosong saya perbaiki dengan arahan tetangga yang sudah terlebih dahulu rumahnya dijadikan Homestay... (Lembaga Desa Wisata Adat Ngadas, wawancara Bulan Januari 2020).

Dengan meningkatnya peluang pada sektor pariwisata memberikan ruang bagi Suku Tengger untuk memperoleh mata pencaharaian. Meningkatkan peluang dapat dilakukan dengan menjalin relasi dan kerjsama melalui promosi. Promosi dilakukan dengan dua cara, konvensional dan online. Konvensional dilakukan dengan mencetak brosur paket wisata dan mengikuti pameran. Media online seperti instagram dan facebook dipilih untuk memberikan jangkauan lebih luas dalam mengenalkan produk wisata yang dimiliki.

Adat istiadat membedakan Suku Tengger dengan suku-suku dan masyarakat lainnya. Adat istiadat dalam sektor pariwisata menjadi aspek penawaran dalam mendatangkan wisatawan untuk mengenal lebih jauh adat istiadat yang dimiliki oleh Suku Tengger.

...Adat istiadat tetap kami lakukan seperti yang diajarkan oleh pendahulu kami dengan bentuk ritual yang sama, bacaan yang sama, dan penanggalan yang sama. Hal ini kami lakukan untuk memberikan pengajaran bahwa dengan tetap melakukan apa yang diajarkan oleh leluhur maka kebaikan akan menyertai hidup ini... (Dukun Desa Ngadas, wawancara Bulan Januari 2020).

Bentuk adat istiadat yang sampai hari ini masih dilakukan adalah ritual, seperti Yadnya Kasada, Pujan, dan Karo Sadranan. Model berpakaian dengan menggunakan sarung yang dipakai setiap keluar rumah dan udeng atau ikat kepala saat ada acara resmi di desa atau di luar desa menjadi ciri khas. Suku Tengger juga memiliki penanggalan sendiri yang bergeser setiap lima tahun. Penanggalan tersebut adalah bulan 1 (Kasa), bulan 2 (Karo), bulan 3 (Katiga), bulan 4 (Kapat), bulan 5 (Kalima), bulan 6 (Kanem), bulan 7 (Kapitu), bulan 8 (Kawolu), bulan 9 (Kasongo), bulan 10 (Kasepoloh), bulan 11 (Desta), dan bulan 12 (Kasada). Wisatawan yang bermalam di Desa Ngadas wajib untuk mematuhi perarturan tertulis yang telah tersedia di homestay.

\section{Strategi Mata Pencaharian}

Sektor pariwisata merupakan bentuk strategi yang dilakukan oleh Suku Tengger Desa Ngadas yang dahulunya hanya memperoleh sumber penghidupan dari sektor pertanian. Pariwisata sebagai strategi penghidupan berkelanjutan (Tao \& Wall, 2009).

a. Strategi diversifikasi

Strategi diversifikasi merupakan kombinasi kegiatan pertanian dan non-pertanian yang bentuknya tergantung kepemilikan modal (Martin \& Lorenzen, 2016). Dengan tidak meninggalkan pekerjaan utama di sektor pertanian, pembagian waktu dilakukan untuk melakukan usaha di sektor pariwisata. Kegiatan ekonomi di desa tidak hanya dari sektor pertanian, akan tetapi aktivitas dan usaha lainnya juga mempengaruhi perekonomian desa (Ellis, 2000). Bentuk strategi diversifikasi dilakukan dengan membuka usaha pariwisata, menanam tumbuhan baru untuk pertanian, dan membuat objek wisata.

Usaha pariwisata yang dilakukan oleh Suku Tengger Desa Ngadas dalam memanfaatkan peluang dari berkembangnya modal penghidupan yang dimiliki. Pariwisata sebagai aktivitas potensial yang bisa 
mendiversifikasi pilihan mata pencaharian dan meningkatkan mata pencaharian keluarga sehingga akan menambah nilai pada kemampuan dan keterampilan keluarga. Kebutuhan mata pencaharian lokal harus diberikan prioritas tinggi pada awal pengembangan pariwisata untuk memastikan bahwa partisipasi masyarakat dan peningkatan kapasitas lokal terjadi selama proses pengembangan untuk membangun hubungan sinergis jangka panjang antara mata pencaharian lokal dan pengembangan pariwisata (Ming, Wall, Wang, \& Jin, 2019). Homestay, jeep, panther, pemandu wisata, olahan makanan, pedagang, dan atraksi kesenian merupakan bentuk dari usaha pariwisata yang dilakukan.

...Saya memandu wisatawan sudah sejak tiga tahun kemarin dengan pengetahuan kepemanduan dari pelatihan yang saya dapatkan. Pelatihan yang saya dapatkan awalnya hanya berupa pariwisata secara umum, dikemudian hari saya yang selalu diutus untuk mengikuti kepemanduan hingga mendapatkan materi tentang kepemanduan. Beberapa orang dari desa mendapatkan fokus pelatihan kepemaduan yang diberikan oleh Ejef hingga sertifikasi profesi. Saat ini pemandu wisata yang tersedia di Desa Ngadas semuanya memiliki sertifikat kompetensi kepemanduan ekowisata... (Lembaga Desa Wisata Adat Ngadas, wawancara Bulan Januari 2020).

Komoditas utama yang sejak dahulu ditanam oleh Suku Tengger di Desa Ngadas dengan sistem tumpang sari terdiri dari 3 macam, Kentang, Kobis, dan Bawang Daun. Memiliki kalender musim tanam dan panen setiap tahunnya 2-3 kali. Adanya perubahan zonasi dai tahun 2016 dan 2019 membuat zona tradisional yang ada di sekitar Desa Ngadas mengalami perluasan. Luas zona tradisional yang berada di sekitar Desa Ngadas atau di wilayah Resort Coban Trisula adalah 1.012 Ha. Tahun 2018 Balai Besar Taman Nasional Tengger Semeru memiliki program pemberdayaan masyarakat dan pemanfaatan zona tradisional. Program ini dijalankan oleh Resorts Coban Trisula selaku yang bertanggung jawab teknis atas wilayah yang didalamnya termasuk Desa Ngadas. Dengan pembentukan kelompok pertanian hutan non kayu dan penanaman tumbuhan terong belanda dan carica yang dapat tumbuh di dataran tinggi. b. Strategi konsolidasi

Pemanfaatan lahan pertanian dan pembagian waktu dengan usaha lain yang dikerjakan dilakukan dalam mencapai penghidupan berkelanjutan. Suku Tengger Desa Ngadas telah melakukan strategi diversifikasi dengan memanfaatkan lahan yang dimiliki dan menggunakan cadangan finansial. Strategi ini menggunakan dana yang disimpan untuk memperoleh dan meningkatan pendaptan (Cogan, Taylor, Wieland, \& Wolters, 2013). Strategi konsolidasi dilakukan dengan pembagian kerja antar anggota keluarga, mempekerjakan buruh, dan menggunakan cadangan finansial.

Hasil yang tidak sedikit didapatkan dari hasil pertanian. Perkiraan perhitungan dilakukan dengan mengetahui jumlah perkiraan pendapatan tahunan sebesar Rp. 113.344.000.000-194.304.000.000. Total perkiraan pendapatan tahunan dibagi dengan Jumlah KK 496. Perkiraan Suku Tengger Desa Ngadas di setiap tahunnya dalam satu kepala keluarga memperoleh penghasilan Rp. 228.516.129-391.741.935. Rata-rata kepemilikan lahan setiap kepala keluarga adalah $1 \mathrm{Ha}$. Sehingga pengelolaan yang dilakukan untuk lahan pertanian dikerjakan bersama. Keterlibatan anggota keluarga dalam usaha pariwisata dapat dilihat dari usaha yang dilakukan.

Homestay melibatkan seluruh anggota keluarga yang ada di rumah. Transportasi akan melibatkan pemilik kendaraan atau kepala keluarga yang dapat mengemudi.

...Homestay yang saya miliki dikelola secara bersama dengan anggota keluarga yang tinggal. Ketika ada wisatawan yang menginap di rumah, maka anggota lainnya akan membagi tugas. Ketika saya sebagai kepala keluarga menerima tamu di pawon, maka istri saya membuatkan minuman dan kudapan. Jika ada anggota lain seperti anak maka kami akan memberikan suasana nyaman seperti senyum, sapa, dan salam jika diperlukan. Interaksi dengan wisatawan akan kami anggap sebagai saudara jauh yang lama tidak ketemu. Akan tetapi wisatawan wajib menaati perarturan yang berlaku dengan peringatan secara lisan dari kami dan membaca perarturan yang telah ditempel... (Lembaga Desa Wisata Adat Ngadas, wawancara Bulan Januari 2020). 
Pemandu wisata melibatkan pemuda yang menguasai bahasa asing untuk memandu. Ibu-ibu dilibatkan dalam olahan makanan. Pedagang asongan yang menjual souvenir penghangat badan dilakukan oleh anak laki-laki berumur belasan tahun. Pedagang warung yang memiliki tempat tetap dilakukan oleh orang tua laki-laki dan perempuan. Kesenian berupa tarian dan musik tradisional dilakukan oleh pemuda dan orang tua dengan tugas yang berbeda.

Pemanfaatan lahan yang meningkat menjadi penyebab adanya buruh yang dipekerjakan di sektor pertanian. Buruh dipekerjakan saat musim tanam dan musim panen yang merupakan puncak kebutuhan pekerjaan tinggi. Upah yang diberikan untuk buruh dihitung dengan hitungan hari dalam bekerja, dengan upah Rp. 75.000 .

Cadangan finansial diperoleh dari sumber penghidupan di sektor pertanian dan pariwisata. Bentuk cadangan finansial yang dimiliki diantaranya adalah simpanan keuangan di bank, dibelikan bentuk fisik lainnya seperti hewan ternak, emas, dan kendaraan. Usaha pariwisata merupakan bentuk salah satu dari cadangan finansial yang dilakukan untuk memperoleh tambahan penghasilan. Hasil di sektor pertanian dialihkan untuk melakukan usaha pariwisata seperti membeli kendaraan, berdagang, dan memperbaiki rumah untuk homestay. Hasil dari pariwisata digunakan untuk memenuhi kebutuhan rumah tangga dan kelebihannya disimpan berupa cadangan finansial.

c. Strategi keamanan

Strategi keamanan adalah mengamankan kepemilikan atau akses ke sumber daya dan aktivitas yang menghasilkan pendapatan, termasuk cadangan dan modal untuk menghadapi resiko, mengurangi guncangan dan memenuhi ketidakpastian (Chambers \& Conway, 1991). Pariwisata memberikan berbagai macam strategi penghidupan termasuk menyediakan layanan sosial, memberdayakan masyarakat dan menghasilkan manfaat budaya.. Munculnya sektor pariwisata sebagai alternatif sumber penghidupan memberikan dampak positif dari pemasukan rumah tangga dengan datangnya wisatawan. Akan tetapi memberikan ancaman terhadap kelestarian lingkungan dan adat istiadat.

Aktivitas Suku Tengger dalam menjaga kelestarian lingkungan dainataranya adalah tidak merusak hutan dengan memperluas lahan pertanian, tidak berburu hewan untuk dikonsumsi dan dipelihara, mengelola sampah hasil rumah tangga, memiliki kepercayaan secara adat istiadat untuk tidak merusak lingkungan, mengurangi aktivitas yang beresiko membakar hutan, dan terlibat dalam pengamanan lingkungan bersama BBTNBTS.

Berbagai macam adat istiadat yang melekat pada modal sosial telah melewati berbagai zaman hingga sampai di zaman ini yang berbeda kondisi. Dipimpin oleh Dukun Tua dan Dukun Muda dalam melaksanakan adat istiadat seperti yadnya kasada, karo, sadranan, unan-unana, petek'an, pujan, entasentas, dan tugel gombak.

...Dalam penghitungan waktu penyelenggaraan adat istiadat ditentukan oleh penanggalan Tengger yang telah kami percayakan perhitungannya ke Dukun. Penanggalan tidak dapat ditentukan orang lain termasuk wisatawan. Sehingga adat istiadat ini tetap sesuai dengan pakem dari nenek moyang dan tidak dapat diubah. Jika wisatawan ingin menampilkan kesenian seperti tarian dan musik tradisional masih dapat disiapkan jika melakukan pemesanan terlebih dahulu... (Kepala Desa Ngadas, wawancara Bulan Januari 2020).

Penentuan waktu untuk adat istiadat mengikuti penaggalan tengger yang telah dilakukan dengan perhitungan. Hal ini menjadikan adat istiadat sebagai bentuk untuk perlindungan terhadap budaya luar karena waktu tidak menyesuaikan disaat kunjungan wisatawan ramai.

d. Strategi kompensasi

Kebutuhan akan pemanfaatan lahan di Desa Ngadas sangat tinggi mengingat bertambahnya jumlah penduduk. 
...Lahan yang saya kelola untuk pertanian merupakan peninggalan dari orang tua yang telah dibagi dengan rata Lahan yang saya kelola ini luasnya kurang lebih satu hektar. Lahan pengerjaannya dibantu oleh anak saya yang umurnya 15 tahun...) (Lembaga Desa Wisata Adat Ngadas, wawancara Bulan Januari 2020).

Lahan di Desa Ngadas terdiri dari lahan produktif dan tidak produktif. Lahan tidak produktif dimiliki oleh persorangan yang letaknya bersebalahan dengan jalan raya dan masih di dalam batas desa. Sehingga sebagian tanah ini digunakan untuk membuka warung dan berjualan makanan dan minuman untuk kebutuhan wisatawan. Lahan produktif merupakan lahan pertanian yang berada di Zona Tradisional dalam sistem pengelolaan TNBTS. Status kepemilikan hanya diperbolehkan untuk Suku Tengger Desa Ngadas. Tanah tidak dapat diperjual belikan dengan orang diluar Desa Ngadas, sehingga tanah hanya dapat disewakan.

\section{SIMPULAN}

Pentagon modal penghidupan berkelanjutan Suku Tengger Desa Ngadas menunjukkan modal alam memiliki nilai tertinggi 52 dengan kriteria tinggi sekali. Modal alam meberikan hasil berupa modal finansial dengan nilai 48 pada kriteria tinggi. Modal alam dan modal finansial mendapatkan nilai dengan kriteria tinggi sekali dan tinggi karena akses terhadap modal fisik dan modal sosial terpenuhi. Modal fisik memiliki nilai 50 pada kriteria tinggi dan modal sosial memiliki nilai 42,5 dengan kriteria tinggi. Kondisi modal manusia dibandingkan dengan lainnya tertinggal dengan nilai 36,3 pada kriteria sedang.

Strategi mata pencaharian dominan yang dilakukan Suku Tengger Desa Ngadas adalah strategi konsolidasi dan strategi keamanan. Strategi konsolidasi dilakukan dengan pembagian kerja antar anggota keluarga, mempekerjakan buruh, dan menggunakan cadangan finansial. Strategi keamanan dilakukan dengan mempertahankan kawasan lingkungan dan budaya dari pengaruh luar. Strategi diversifikasi tetap dilakukan dengan membuka usaha pariwisata dan menanam tanaman baru di lahan pertanian. Strategi yang tidak dilakukan adalah strategi kompensasi dengan menjual tanah milik pribadi yang tidak produktif. Hal ini dilarang secara norma dan adat istiadat karena kepemilikan lahan di Desa Ngadas hanya dimiliki Suku Tengger Desa Ngadas. Orang luar dapat memanfaatkan lahan di Desa Ngadas dengan status sewa.

\section{DAFTAR REFERENSI}

Ahebwa, W. M. (2012). Tourism, livelihoods and biodiversity conservation.

Ashley, C. (2000). The Impacts of Tourism on Rural Livelihoods : Namibia's Experience. Working Paper Overseas Development Institute, 128, 6-23.

Batoro, J. (2012). Etnobiologi masyarakat tengger di bromo tengger semeru jawa timur. Disertasi Sekolah Pascasarjana IPB.

BBTNBTS1. (2019). Dokumen Zona Pengelolaan Taman Nasional Bromo Tengger Semeru Tahun 2019.

BBTNBTS2. (2018). Statistik Balai Besar Taman Nasional Bromo Tengger Semeru Tahun 2018.

BBTNBTS3 (Balai Besar Taman Nasional Bromo Tengger Semeru). 2019. Paparan BBTNBTS dalam Multi Stakeholders Dialogue Melihat Prespektif Pemangku Kepentingan atas Upaya Pengarustamaan Hak Asasi Manusia dala Industri Pariwisata di Indonesia: Studi Kasus Kawasan Pariwisata Bromo Tengger Semeru Diselenggarakan Kemenkumham 26 November 2019 di Surabaya.

BBTNBTS4 (Balai Besar Taman Nasional Bromo Tengger Semeru). 2018. Laporan Monitoring dan Pendampingan Kegiatan Desa Binaan di Desa Ngadas Tahun 2018.

BPS (Badan Pusat Statistik) Kabupaten Malang. 2019. Kecamatan Dalam Angka 2018.

26 |Jurnal Kepariwisataan: Destinasi, Hospitalitas dan Perjalanan, Volume 4 Nomor 1, 2020: 11-28 
Chambers, R., \& Conway, G. R. (1991). Sustainable Rural Livelihoods: Pratical Concepts for The 21st Century. IDS Discussion Paper 296, 1-27.

Cogan, J. F., Taylor, J. B., Wieland, V., \& Wolters, M. (2013). Fiscal consolidation strategy: An update for the budget reform proposal of march 2013. IMFS Working Paper, 68.

Coleman, J. 2010. Dasar-dasar Teori Sosial, Bandung: Nusa Media.

Cornelius, W. A., Tsuda, T., \& Valdez, Z. (2003). Human Capital versus Social Capital A Comparative Analysis of Immigrant Wages and Labor Market Incorporation in Japan and the United States. MIGRACIONES INTERNACIONALES, 2(1), 5-35.

DFID (Department for International Development). 2001 Sustaianable Livelihoods Guidance Sheets. Number 1-8, London: Department for International Development. Diunduh melalui www.livelihoods.org pada tanggal 17 Januari 2020.

Disparbud (Dinas Pariwisata dan Kebudayaan) Kabupaten Malang. 2020. Jumlah Kunjungan Wisatawan Kabupaten Malang Tahun 2017-2019.

Ellis F. 2000. Household Strategies and Diversity in Developing Countries, Oxford: Oxford University Press.

ESDM Jatim. 2014. Kondisi Geologi Jawa Timur. Diakses melalui esdm.jatimprov.go.id pada tanggal 17 Januari 2020.

Field, John. 2010. Modal Sosial. Jakarta: Kreasi Wacana.

Jawapos.com. 2019. Kebakaran Hutan Kembali Terjadi di Desa Ngadas Poncokusumo. Diakses pada tanggal 18 Januari 2020.

Lestari, Dwi Evi. 2013. Kajian Bahaya Tanah Longsor dan Upaya Mitigasi Oleh Masyarakat Gunung Api Tengger. Yogyakarta: Tesis UGM.

Lembaga Desa Wisata Adat Ngadas, Kepala Desa Ngadas, Dukun Desa Ngadas, Kepala SPTN 2 BBTNBTS, dan Kasi Destinasi Wisata Alam dan Buatan Disparbud Kab. Malang. (Desember 2019-Januari 2020). Hasil Wawancara.

Martin, S. M., \& Lorenzen, K. (2016). Livelihood Diversification in Rural Laos. WORLD DEVELOPMENT, $x x, 1$ 1-13. https://doi.org/10.1016/j.worlddev.2016.01.018

Mbaiwa, J. E., \& Stronza, A. L. (2010). The effects of tourism development on rural livelihoods in the Okavango Delta , Botswana. Journal of Sustainable Tourism, 18(5), 635-656. https://doi.org/10.1080/09669581003653500

Ming, M., Wall, G., Wang, Y., \& Jin, M. (2019). Livelihood sustainability in a rural tourism destination - Hetu Town , Anhui. Tourism Management, 71, 272-281. https://doi.org/10.1016/j.tourman.2018.10.019

Qian, C., Sasaki, N., Jourdain, D., Minsun, S., \& Shivakoti, P. G. (2017). Local livelihood under different governances of tourism development in China e A case study of Huangshan mountain area. Tourism Management, 61, 221-233. https://doi.org/10.1016/j.tourman.2017.01.006

Scoones, I. (2009). Livelihoods perspectives and rural development Livelihoods perspectives and rural development. The Journal of Peasant Studies, 36(1), 171-196. https://doi.org/10.1080/03066150902820503

Shen, F., Hughey, K., \& Simmons, D. (2008). CONNECTING THE SUSTAINABLE LIVELIHOODS APPROACH AND TOURISM: A REVIEW OF THE LITERATURE TOWARD INTEGRATIVE THINKING. CAUTHE 2008 Conference, 1-14.

Simpson, M. C. (2007). An integrated approach to assess the impacts of tourism on community development and sustainable livelihoods. Oxford University Press and Community Development Journal, 44(2), 186-208. https://doi.org/10.1093/cdj/bsm048

Stroombergen, A., Rose, D., \& Nana, G. (2002). Review of the Statistical Measurement of Human Capital. Statistics New Zealand, (November), 1-52.

Tao, T. C. H., \& Wall, G. (2009). Tourism as a sustainable livelihood strategy. Tourism Management, 30(1), 90-98. https://doi.org/10.1016/j.tourman.2008.03.009

Undang-undang nomor 20 tahun 2003 tentang Sistem Pendidikan Nasional.

VSI ESDM. 2020. Laporan Kebencanaan Geologi 17 Januari 2020. Diakses melalui vsi.esdm.go.id pada tanggal 17 Januari 2020. 
Widyasari, K., Hakim, L., \& Yanuwiadi, B. (2013). KAJIAN JENIS - JENIS BURUNG DI DESA NGADAS SEBAGAI DASAR PERENCANAAN JALUR PENGAMATAN BURUNG (Birdwatching). Jurnal of Indonesia Tourism and Development Studies, 1(3), 108-114.

Zaennudin, A. (2011). Perbandingan antara erupsi Gunung Bromo Tahun 2010 - 2011 dan erupsi Kompleks Gunung Tengger, 2(1), 21-37. 